\title{
SOCIAL ACCOUNTING - SOURCE OF RELEVANT INFORMATION IN ASSESSING THE SOCIAL RESPONSIBILITY OF THE ORGANIZATION
}

\author{
Carmen-Florentina Păunescu \\ Doctoral School of Economic Sciences, Faculty of Economics and Business Administration, \\ University of Craiova, Craiova, Romania \\ carmenpetre1980@yahoo.com
}

\begin{abstract}
At present, accounting efforts have been extended to assessing the state of society and social programs, not for the satisfaction of any individual or group, but for the application of evaluation procedures in the allocation of resources to a better social welfare. In this paper we try to find the answer to the following questions: Is the accounting information relevant to the social responsibility assessment of the organization? What are the tools for measuring the degree of social responsibility achievement and what are the sources of information on which they are based? What are the characteristics and benefits of knowing and applying social accounting?

The product provided by accounting is the information and, like any other product, in order to be accepted by customers, it must meet certain qualitative criteria, certain standards to satisfy the needs of the beneficiaries. Social objectives are less common in organizations' strategies, but with a rapid growth trend over the last decade, especially for large and medium-sized organizations, with these objectives referring to: pollution control, cooperation with authorities, waging and working conditions of employees, customer satisfaction through the quality, durability, flexibility and price of the products and services offered, making suppliers permanent in return for offering quality products at affordable prices and upon the agreed deadlines.
\end{abstract}

Keywords: corporate social responsibility, accounting information, social accounting, social accounting matrix.

JEL classification: M14, M40, M41.

\section{Introduction}

Only the operations that affect the patrimony and which can be expressed in a monetary form are included in the scope of the accounting subject matter. This use of currency, as a way of estimation, has the advantage of allowing the combination of the value of very different, and thus Heterogeneous, objects into a homogeneous entirety of the organization (Barney,1991).

But this use of the currency as a measure of value is not free of inconveniences and from here devolve the limits for the accounting information system. First of all, the currency is not a measure of universal value, so it will be difficult and delicate to give a monetary expression to some events that are not related to the non-commercial, which are consequently ignored by accounting. 
But in the not too far future, under the incidence of applying this principle the elements that are not and do not seem to be quantifiable will have to be included, elements such as (Carroll, 1979):

- $\quad$ the competence of the employees;

- the social performance of the organization;

- $\quad$ the managerial capacity of its leaders;

- $\quad$ the creativity capacity of a research team;

- the social climate;

- the degree of pollution;

- $\quad$ the quality of the environment in which the organization operates;

- $\quad$ the intensity of the restrictions imposed by the environment, etc.

In economically developed countries, we speak more and more about human resources accounting and environmental accounting, which requires changes in the structure of synthetic accounting documents (Gallardo and Sánchez, 2013).

\section{Research Methodology}

The paper has been prepared based on a qualitative research consisting in the study, synthesis and observation of some papers and studies from the literature, for finding and analyzing instruments that measure the degree of social responsibility achievement as well as models of off-balance sheet boards according to national, international and European references.

In order to achieve the objective of qualitative research, we studied the literature to determine tools for analyzing social elements in the work of organizations, namely the social accounting matrix, which is both a source of relevant information in assessing the social responsibility of the organization and an important tool for analyzing and substantiating micro- and macroeconomic policy decisions.

\section{Brief Literature Review}

In the history of social accounting, an important role has been played by its inventor, Stone, a British economist, winner of the Nobel Prize for Economics in 1984, who is also linked to the difficult history of developing and improving the national account system (NAS).

The first reflections of Stone and his collaborators on social accounting date back to the 1960s, when national accounting recorded some progress, largely due to Stone. At the same time, statistically evolved countries had gained some experience in compiling accurate and reliable calculations for the main macroeconomic aggregates and building national accounts, even if they were made independently and were not organized or coordinated within an economic system. This economic system is a philosophy on which models of quantitative description of activities taking place in a national economy are based. From the point of view of defining the Social accounting matrix in the field of accounting, in his work "Social Accounting Matrices and SAM-based Multiplier Analysis" (Round, 2014) draws up a presentation of the accounts in a matrix that exposes in a detailed way the relationships between a resource and usage table and sector accounts. The main characteristic of this matrix is the flexibility, in terms of the possibility of detailing or aggregating, according to the purposes of the analysis, to the available data sources, to the statistical potential of the person building it.

Neculai Tabara in his paper entitled "Modernizing accounting and management control. News and perspectives"(2006), has brought together all the elements of great interest for a social responsibility management structure within an organization can be grouped in a non-financial board. 
Regarding the issue approached, the literature offers few theoretical and practical studies related to social accounting regarding the emergence, role, necessity, organization and management in specific environments, instruments of realization, with the mention that these studies concern the private sector.

\section{The tools for measuring the degree of social responsibility achievement}

Matrix presentation is a tool that allows the full exploitation of the reliability of the system of national accounts. Thus, for example, it will be possible to analyze in more detail the existing relations between its social and economic aspects, and that in order to reach a social accounting matrix.

The social accounting matrix is defined as a presentation of accounts within a matrix that exposes in a detailed way the relationships between a resource and usage table and sectorial accounts (Zadek, 2005). The main feature of this matrix is flexibility, in terms of the possibility of detailing or aggregating, depending on the purposes of the analysis, by the available data sources, by the statistical potential of the one building it. Of course, it is possible to develop only aggregates that characterize sectorial functions or aggregates. This flexibility makes this matrix very useful in the context of national accounting. At the same time, a social accounting matrix integrates revenue and expenditure flows and input output tables at a mesoeconomic level, it can serve as a model for estimating a wide variety of accounts. The social accounting matrix method is particularly useful when one wishes to reconcile detailed information on international production and trade, with primary data coming from, for example, an enquiry on labor force, family budgets, or on investments by activity branches. Integrating a larger volume of primary data allows analyzing and tracking a larger number of aspects regarding the correlation relationships that they can generate. Also, the social accounting matrix allows us to know the existing relationships between the use of labor force and the distribution of income and the objectives of a macroeconomic perspective such as gross domestic product (GDP), balance of payments, price stability, etc.

The social accounting matrix also provides a coherent data frame for overall balance models regarding the economy entirety, which has detailed classifications of various agents, especially by branch of activity, by types of labor force and by subgroups of households. At the same time, the basic scheme of the system of national accounts is faithfully reflected by the social accounting matrix, the latter perfectly combining macroeconomic and microeconomic theory.

The matrix of social accounting can be found in both the input-output table, and also the flows that allow detailed analysis of the process of distribution, redistribution and use of revenues, this facility being particularly important in the context of elaborating and substantiating macroeconomic policies regarding economic restructuring or some analyses of the mechanisms of formation and maintenance of national wealth and population welfare. As a sole accounting system, in which there are the transactions between agents, explicitly followed, the social accounting matrix has an additional recourse as the basis for a macro and micro level by the simple analysis and modeling of the multiplier.

However, there are some important limitations that should be kept in mind by a new analyst. First of all, there is no final social accounting matrix because the framework is flexibly established around a standard basic structure. Detailed classifications should be chosen depending on criteria specific to each country in order to best reflect the organization. In order to be truly informative, the revenue record must be represented around the system, relatively detailed and complete, otherwise the content of the information will be constrained by the weakest in the chain. Secondly, it should be emphasized that it is not always possible to use data sets without a specific requirement to adjust the value. 
For example, because the national accounts are not always compiled, the enquiry data of the organizations, it is not easy to rationalize the two data sources, and this does not apply only to the expenses of the organizations, but also to their incomes. An important role in the history of social accounting was played by its inventor Stone (1962), who is also linked to the history full of difficulties in elaborating and perfecting the system of national accounts (SNA). The first reflections of Stone (1962) and his collaborators on social accounting date back to the 60's, when national accounting recorded some progress, largely due to Stone himself. The social accounting matrix allows the development of models, including the general balance, to analyze the various correlations between training, distribution, redistribution of government revenues and expenditures by different sectors of activity. Insofar as it is detailed and by including the transactions with the rest of the world, thus surpassing the situation of a closed economic system, the possibility of the integration of a national economy into the international circuit appears. There is a close connection between social accounting and financial accounting, even if they have a different construction.

An accounting matrix must present a coherent structure of social accounting data. The requirement of such an approach is that totals rows are equal to total columns to provide a useful way of keeping control of all social phenomena - economic, while avoiding any form of duplication. A matrix of social accounts forms the basis for almost all disaggregated economic models. Expenses are listed in matrix columns and receipts are recorded in rows. In order for the sum of all expenses made by a certain account (or sub-account) to be equal to the total amount of receipts or income for the corresponding account, the amounts of rows must be equal to the column sums in the corresponding account.

For example, the total revenue of a given organization must be equal to exactly the total expenditure of the same organization. Therefore, analysts interested in understanding how the production structure influences the distribution of revenue can get useful information by studying a social accounting matrix. The classification of expenditures incurred and earnings is essential if the social accounting matrix is used as a diagnostic tool to better understand the socio-economic interdependencies, the structure of an economy, or as a conceptual framework. A social accounting matrix should meet the following requirements:

- reproduce properly the socio-economic and structural (production) structure in society and economy;

- $\quad$ to distinguish relatively homogeneous groups and categories;

- be composed of socio-economic groups that are recognized and useful for socio-economic analysis (ie specific target groups should be identified);

- be based on relatively stable characteristics that can be measured relatively easily and reliably;

- can be derived from existing data sources.

There is no single (standard) classification or disaggregation scheme and data organization for a social accounting matrix.

\section{The social accounting of the organization}

Social Accounting is a structure that organizes all flows of an economic system, expressed as values, in a coherent manner and an accounting perspective. The starting point in the construction of social accounting is the elementary flows representing the transactions that are carried out between the elementary economic subjects of an economic system (Man and Ciurea, 2016). Considering that the fundamental purpose of national accounting is represented by the coherent description of a reasonable number of macroeconomic aggregates, a particularly important aspect refers to the aggregation of elementary flows up 
to the desired aggregation level. In order achieve this operation, attention shifts from flows to subjects. These subjects are grouped based on two fundamental criteria, thus (Man and Macris, 2015):

- who is the subject in question;

- $\quad$ why the subject does carry out a particular transaction.

This way it is possible to obtain groups in which the subjects are regrouped in institutional sectors based on the importance of various subjects from the legal and social point of view, as well as in functions that refer to the behavior of these institutions when they are producing, consuming or saving. All these methods of analysis can be combined with each other in a matrix in which, conventionally, the lines represent the inputs, and the columns represent the outputs (Smita, 2012). There is a close link between social accounting and financial accounting, even if they are differently built. The matrix formula on which social accounting is based allows for establishing links between the financial and non-financial accounts of institutional sectors and their presentation in a single picture of the national economy at a given time. Environmental protection measures include all those activities initiated to comply with the organization's internal and external regulations, whether voluntary or mandatory. At the same time, the social accounting fulfils the following characteristics according to Figure 1:

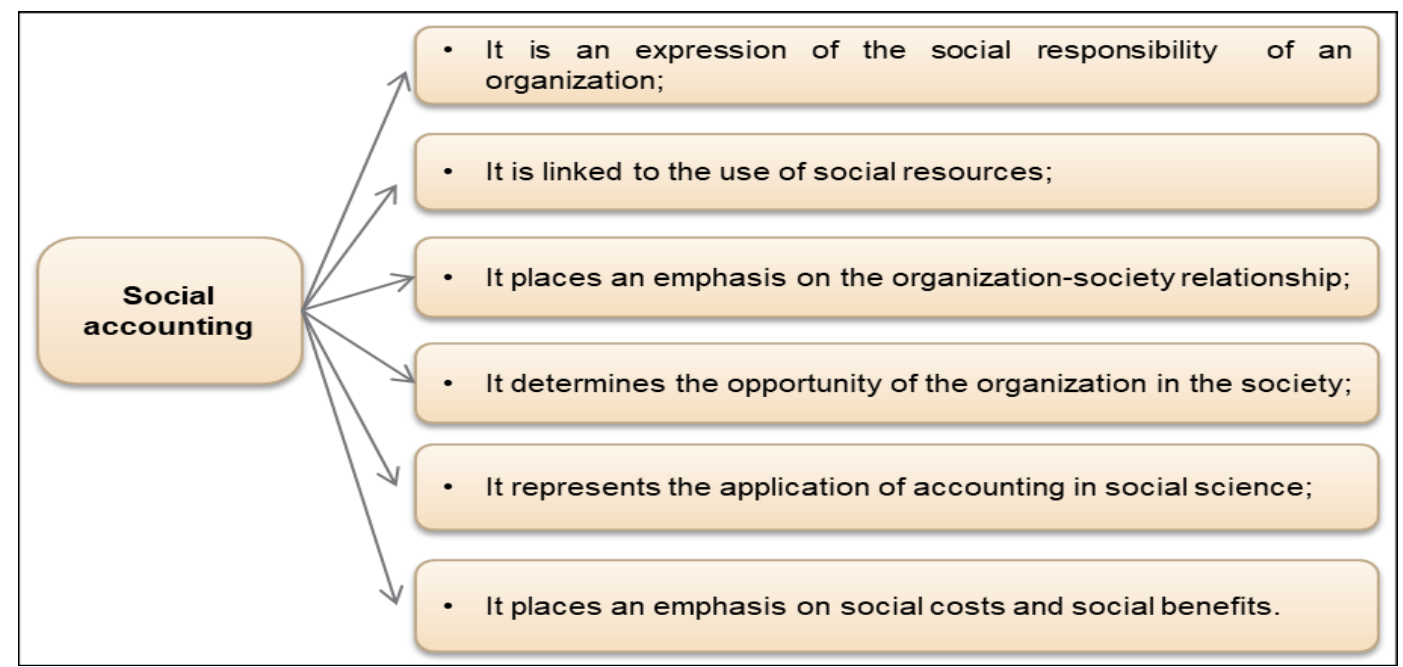

Figure 1. Features of social accounting

Source: Adapted and processed after Lantos, (2001::3-9).

The criterion of this compliance is not of an economic nature but has the effect of preventing or reducing the environmental impact. Social costs are the main strategic goal of a corporate social responsibility (CSR) plan within an organization (Beurden and Gössling, 2015). They occur when communities are compensated for damage caused by organizations. All the elements of great interest for a social responsibility management structure within an organization can be grouped in the form of a non-financial board (Table 1): 
Table 1: Off-balance sheet board

\begin{tabular}{|c|c|c|}
\hline Field & $\begin{array}{l}\text { Topics to be assessed as social } \\
\text { and environmental performance }\end{array}$ & $\begin{array}{c}\text { Elements to be assessed as } \\
\text { immaterial capital }\end{array}$ \\
\hline Clients & $\begin{array}{l}\text { Quality of products or services; } \\
\text { Security of products; } \\
\text { Ecology of non-polluting, } \\
\text { recyclable, biodegradable } \\
\text { products, etc.; } \\
\text { Ethics of business development; } \\
\text { Ethics of sales policy. }\end{array}$ & $\begin{array}{l}\text { Customer loyalty; } \\
\text { Profitability of customers; } \\
\text { Financial health and solvency of } \\
\text { customers; } \\
\text { Durability of competitive advantage } \\
\text { and weariness of supply. }\end{array}$ \\
\hline Employees & $\begin{array}{l}\text { Fundamental human rights } \\
\text { Compliance with employee rights } \\
\text { requirements; } \\
\text { Working conditions; } \\
\text { Remuneration of employees; } \\
\text { Hygiene and security, etc. }\end{array}$ & $\begin{array}{l}\text { Employee loyalty; } \\
\text { Employee competence; } \\
\text { Motivation; } \\
\text { The internal climate and the spirit of } \\
\text { cooperation among the employees; } \\
\text { Sharing organizational values, etc. }\end{array}$ \\
\hline Shareholders & $\begin{array}{l}\text { The new management; } \\
\text { Their social and environmental } \\
\text { responsibility. }\end{array}$ & $\begin{array}{l}\text { Stability, understanding, long-term } \\
\text { shareholders' mood, etc. }\end{array}$ \\
\hline Suppliers & $\begin{array}{l}\text { Ethics of business relations; } \\
\text { Ethics of purchasing policy. }\end{array}$ & $\begin{array}{l}\text { Quality of products and services; } \\
\text { Durability of suppliers; } \\
\text { Adapting suppliers' portfolio to } \\
\text { needs. }\end{array}$ \\
\hline Structure & & $\begin{array}{l}\text { Research and development } \\
\text { expenses; } \\
\text { The science of developing patents, } \\
\text { trademarks; } \\
\text { The information system; } \\
\text { The organization performance; } \\
\text { Reliability, quality and flexibility of } \\
\text { the means of production }\end{array}$ \\
\hline Civil society & $\begin{array}{l}\text { Patronage; } \\
\text { Subsidies for NGOs; } \\
\text { Subsidies for programs meant for } \\
\text { the population; } \\
\text { Subsidies for educational } \\
\text { programs, etc. }\end{array}$ & $\begin{array}{l}\text { Stability of the social environment; } \\
\text { The performance of infrastructure } \\
\text { etc. }\end{array}$ \\
\hline
\end{tabular}

Source: Tabara N., 2006

However, they also refer to externalities where costs have not yet been internalized (damage to the health of neighbouring communities, to agricultural crops or waters, etc.).

Costs involving stakeholders fall within the same framework of social costs. They include, in addition to costs for the local community, other costs related to: investors, creditors, regulators, customers, government organizations or NGOs, etc. By maintaining good relationships with these stakeholders, an organization avoids undesirable environmental conflicts. Building a green organization image helps to bring about economic welfare opportunities. The limits of conventional accounting principles, practices and abilities have been extended to such areas for social disclosure and attestation of social programs measures. 
The concept of social accounting has gained special importance as a result of high-level industrialization, which brought prosperity to society as well as many problems (Schaltegger and Burritt, 2000). This has forced the corporate sector, with huge amounts of funds, to invest substantial sums in social activities in order to overcome the negative effects of industrialization.

\section{Conclusion}

In conclusion, the social accounting matrix represents an important tool of macroeconomic analysis and, at the same time, of substantiation of micro- and macroeconomic policy decisions. We can argue that, when an organization decides to invest in a certain community, to conclude contracts with business partners, to hire employees, they make promises, based on which the interested parties change their expectations and life plans. In this case, the management of that organization should take their interests into account in the same way that it considers the interests of the shareholders.

From the perspective of business ethics, determining whether the interests of one or the other should prevail within a business organization would represent the solution to a problem. In the context of business ethics, the concept of an interested party can be extended to all those who are affected, one way or another, by the activity of an organization. From this perspective, the parties interested in business organizations activity are not just the owners, the shareholders, but also the employees, the business partners, even the members of the community in which the organization operates. Business is a socio-economic activity that attracts contributions from society, therefore its goal should be the wellbeing of society and should have a responsibility to solve many social problems (Torugsa, O'Donohue and Hecker, 2012).

Currently, on an increase in technological, economic, cultural and social awareness, accounting not only fulfils its function of managing the owners of organizations, but also fulfils its social function. Changing media and social parameters has prompted organizations to account for and report information regarding the fulfilment of social responsibilities.

So far, accounting efforts have been extended to assessing the state of society and social programs, not for the satisfaction of any individual or group, but for the application of evaluation procedures in the allocation of resources to better social welfare. Social accounting deals with analyzing and studying the accounting practice of those activities of an organization. The concept of the socialist model of society, civil rights movements, environmental protection groups and ecological conservation groups, the increase of the awareness of the society towards the social contribution of the organizations contributed to the increase in the importance of social accounting. Social accounting, also known as social responsibility, socio-economic accounting, social reporting and social audit, aims at measuring and informing the general public about the social assistance activities undertaken by the entity and their effects on society (Barnett, 2007). Social accounting should also be seen as a cost-benefit ratio for engaging in the field of pollution control, safety and health, and other beneficial societal requirements, and generally be able to measure the impact of the entity on the environment.

The contribution of the article is that it can be considered as a starting point for possible future ways for wider research to measure relevant information from social accounting because we can consider accounting information to be relevant to assessing the organization's social responsibility and tools for measuring degree the achievement of social responsibility and the sources of information on which it is based is given by social accounting itself. 


\section{References}

Barney, J., 1991. Firm resources and sustained competitive advantage. Journal of Management, 17 (1), pp. 99-120.

Barnett, M.L., 2007. Stakeholder influence capacity and the variability of financial returns to corporate social responsibility. Academy of Management Review. 32 (3) pp. 794-816.

Beurden, P. and Gössling, T., 2015. The worth of values - a literature review on the relation between corporate social and financial performance. Business Ethics, 82 (2), pp. 407-424. Carroll, A.B., 1999. Corporate Social Responsability: Evolution of a Definitional Construct, Business \& Society, 38 (3), 268-295.

Gallardo, V. and Sánchez, H., 2013. Measuring Corporate Social Responsibility for competitive success at a regional level. Journal of Cleaner Production, 72, pp. 14-22.

Lantos, G.P., 2001. The Boundaries of Strategic Corporate Social Responsibility. Journal of Consumer Marketing, 18 (17), pp. 3-9.

Man, M. and Ciurea, M., 2016. Transparency of accounting information in achieving good corporate governance. True view and fair value. Social Sciences and Education Research Review, 3 (1), pp. 41-62, Available at: http://sserr.ro/wp-content/uploads /2016 105/3-1-41-62.pdf, [Accessed 2 Nov 2018].

Man, M. and Macris, M., 2015. Integration of Corporative Governance into Organisation s Social Responsability System. Polish Journal of Management Studies, 11 (2), pp. 100-114, Available at: http://www .pjms.zim.pcz.pl/-articles.php, [Accessed 4 Nov 2018].

Round, J., 2014. Social Accounting Matrices and SAM-based Multiplier Analysis Available at: http://siteresources.worldbank.org/INTPSIA/Resources/490023-1121114603600/14017 chapter14.pdf. [Accessed 3 May 2018].

Schaltegger, S. and Burritt, R., 2000. Contemporary Environmental Accounting. Issues, concepts and practice. London: Greenleaf Publishing.

Smita, M., 2012. Social Accounting: Concept, Definition, Features and Benefits/Financial Analysis. [online] Available at: http://www. yourarticlelibrary.com/accounting/social-accounting/social-accounting-concept-definition-fe atures-and-benefits-financial-analysis/67 703, [Accessed 6 May 2018].

Stone, R., 1962. A Social Accounting Matrix for 1960, No. 2 in A Programme for Growth. London: Chapman and Hall.

Tabara, N., 2006. Modernizing accounting and management control [Modernizarea contabilităţii şi controlului de gestiune]. lasi: TipoMoldova Publisher.

Torugsa, N.A., O'Donohue, W. and Hecker, R., 2012. Capabilities, proactive CSR and financial performance in SMEs: empirical evidence from an Australian manufacturing industry sector. Business Ethics, 109 (4), pp. 483-500.

Zadek, S., 2005. Responsible competitiveness: Reshaping global markets through responsible business practices, Corporate Governance. The International Journal of Business in Society, 6 (4), pp. 334-348, Available at:<https://doi.org/ 10.1108/14720700610689469, [Accessed 1July 2018].

\section{Bio-note}

Paunescu Carmen Florentina is PhD student in the second year at the Doctoral School of Economic Sciences, University of Craiova, PhD Domain: Accounting. As a PhD student, he focused on studying the social responsibility activities of organizations. 